\title{
Fish disease monitoring along a pollution transect: a case study using dab Limanda limanda in the German Bight
}

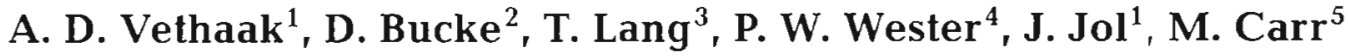 \\ ${ }^{1}$ Ministry of Transport and Public Works, Public Works Department, Tidal Waters Division, Ecotoxicology Section, \\ PO Box 20906, 2500 EX The Hague. The Netherlands \\ ${ }^{2}$ Ministry of Agriculture, Fishery and Food, Directorate of Fisheries Research, Fish Diseases Laboratory, 14 Albany Road, \\ Granby Industrial Estate, Weymouth, Dorset DT4 9TH, United Kingdom \\ ${ }^{3}$ Bundesforschungsanstalt für Fischerei, Aussenstelle Cuxhaven, Deichstr. 12, W-2190 Cuxhaven, Germany \\ ${ }^{4}$ National Institute of Public Health and Environmental Protection, Laboratory for Pathology, PO Box 1, \\ 3720 BA Bilthoven, The Netherlands \\ ${ }^{5}$ Plymouth Marine Laboratory, Prospect Place, West Hoe, Plymouth, Devon PL1 3DH, United Kingdom
}

\begin{abstract}
A survey of dab Limanda limanda at 6 stations along a pollution gradient in the German Bight was conducted as part of the Bremerhaven Workshop in order to quantify spatial patterns of 5 selected gross pathologies. The objective was to test the suitability of disease epidemiology and related histological investigations in this species as a technique for monitoring environmental quality in offshore waters. In 2 surveys, 7565 dab (length $\geq 15 \mathrm{~cm}$ ) were examined post-mortem and the following externally visible diseases (with overall prevalences) were recorded: lymphocystis (10.5\%), epidermal hyperplasia/papilloma $(6.2 \%)$, acute and healing ulcerations $(1.7 \%)$ and X-cell gill disease $(0.4 \%)$. In the 1st survey, a total of $686 \mathrm{dab}$ (length $\geq 25 \mathrm{~cm}$ ) were screened internally for nodular lesions (diameter $\geq 2 \mathrm{~mm})$ on the liver surface. These liver nodules represented presumptive neoplasia $(5.8 \%)$. Histological examination confirmed $30 \%$ of these lesions as neoplastic (hepatocellular adenoma). $27.5 \%$ as foci of cellular alteration (putative pre-neoplastic lesions). $35 \%$ as other lesions, including cysts, parasitic lesions, fibrosis and necrosis, whereas the remaining $7.5 \%$ revealed no significant abnormalities. Histological investigation of $110 \mathrm{dab}$ livers displaying no gross nodules revealed a similar spectrum of lesions, but without any evidence of neoplasia. The spatial patterns for the 2 most common diseases were analysed using a linear logistic model to incorporate main effects and interaction effects of length, age and sex. The prevalence of epidermal hyperplasia/papilloma decreased with distance offshore, in accordance with contaminant concentrations, whereas lymphocystis showed the opposite trend. The spatial patterns of the other disorders were not statistically analysed due to low prevalence values and revealed no clear trend, with the possible exception of skin ulcerations which showed high prevalences at the outermost station. Significant positive correlations were found between the prevalence of epidermal hyperplasia/papilloma and contaminants in the liver of dab, but again lymphocystis showed the opposite trend. None of the other disorders, including the gross and histologically identified liver lesions, showed any apparent relationship with the chemical data. The findings of the workshop, in conjunction with the available evidence from other studies, indicated that the most promising external disease for biological effects monitoring appeared to be epidermal hyperplasia/papilloma. Putative pre-neoplastic and neoplastic liver lesions, although only found at low prevalences in this study, have been recommended as a suitable internal disease for use in biological effects monitoring. However, before these diseases can be used as reliable indicators, further research is required on migration patterns of the dab, the natural background levels of disease, and on disease induction in the laboratory. Future monitoring studies using dab diseases may require larger sample sizes than the minimum recommended by ICES. In studies of liver nodules, the inclusion of histological techniques is strongly recommended.
\end{abstract}




\section{INTRODUCTION}

During the past 20 yr there has been an increasing number of field surveys to investigate the suitability of fish epidemiology, including histopathological investigations, for monitoring the effects of marine pollution. Although most of these studies show that disease induction is multifactorial, they have provided evidence that pollution is implicated in the aetiology of some diseases (Sindermann et al. 1980, Bucke \& Watermann 1988, Vethaak \& ap Rheinallt 1992).

The Bremerhaven Workshop during March 1990 was designed to test and compare potential techniques for monitoring the biological effects of pollution along transects in the southeastern North Sea. The dab Limanda limanda was chosen as it is one of the principal organisms used for monitoring purposes, e.g. by the North Sea Task Force. The species is particularly susceptible to disease, frequently showing grossly visible lesions.

In the present study, spatial patterns of 5 gross disorders in the dab were quantified along a transect of 6 stations in the German Bight. During the field work, the guidelines published by the International Council for the Exploration of the Sea (ICES) (ICES 1989) on methods for fish diseases surveys were used. The gross disorders examined post-mortem included lymphocystis, epidermal hyperplasia/papilloma, skin ulceration, 'X-cell' lesions of the gill, and liver nodules' tumours. The identification of gross lesions was later confirmed histologically. In addition, a histological examination of dab livers showing no obvious lesions at the gross level was carried out.

The case study reported here gives special emphasis to sampling techniques and statistical analysis of the epidemiological data. The possible relationships between fish diseases and environmental pollution are assessed, and the difficulties of demonstrating causeand-effect relationships are discussed. In addition, recommendations are given for future studies of dab diseases and their use in biological effects monitoring.

\section{MATERIAL AND METHODS}

Fish sampling. Two replicate surveys over 6 stations (Stns 3, 5 \& 6 to 9) selected from those used by the workshop (see Stebbing \& Dethlefsen 1992) were conducted with research vessels of the German Federal Research Board for Fisheries. They extended from the inner German Bight (the mouth of the river Elbe) to the Dogger Bank. The 1st survey, with RV 'Solea', lasted from March 12 to 17, 1990, and the 2nd survey, with RV 'Walther Herwig', from March 22 to 26, 1990. During both cruises fish were caught using bottom trawls equipped with a cod-end (mesh size $32 \mathrm{~mm}$ ). Further details on sampling techniques are given by Rijnsdorp et al. (1992).

First survey: Two or more hauls were taken along different tracks through the centre of the fixed co-ordinates of each station (Rijnsdorp et al. 1992). Although taking hauls along the same track would have minimised haul-to-haul variation, the procedure adopted ensured that the value of prevalence obtained was representative of the station as a whole. Each tow lasted 60 min and towing speed was between 3 and 4 knots.

After each haul, dab were sorted from the total catch, or from representative subsamples. The length-frequency distribution was recorded (total length to the nearest $\mathrm{cm}$ below) for females and males separately. Measured dab were sorted according to length class $(15-19 \mathrm{~cm}, 20-24 \mathrm{~cm}, \geq 25 \mathrm{~cm})$ prior to examination for gross lesions. Random samples of fish from each class were then taken, the sample sizes following the ICES guidelines as far as possible (Table 1).

Condition factors $(\mathrm{CF})$, somatic liver indices (SLI), and somatic gonadal indices (SGI) were caiculated for a subsample of 50 gutted female fish $(20-24 \mathrm{~cm}$ length) as indicators of the physiological/reproductive status of the fish at the different stations. These fish were deepfrozen on board and later weighed in the laboratory. CF was calculated as:

$100 \times$ somatic wt in $\mathrm{mg} /$ (total length in $\mathrm{mm})^{3}$.

SLI and SGI were then calculated as:

Total liver or gonadal wt/(100 $\times$ somatic $w t$ in $\mathrm{mg})$

The catch-per-hour data were used to estimate the relative population density of dab for each station (Rijnsdorp et al. 1992).

To assess the relationship between disease occurrence and age, disease prevalences (in $\mathrm{cm}$ length classes) were translated into prevalences according to the age class using age/length keys for the 2 sexes separately (Rijnsdorp et al. 1992).

Second survey: The 2nd survey was conducted to provide a replicate data set for the external diseases, and to collect additional liver samples for histological investigation.

Table 1. Length-stratified sampling design with minimum sample sizes per haul/station for recording of externally visible diseases and liver nodules. (Modified from ICES 1989)

\begin{tabular}{|lcl|}
\hline $\begin{array}{l}\text { Length } \\
\text { group }\end{array}$ & $\begin{array}{c}\text { Minimum number } \\
\text { of dab to be } \\
\text { examined }\end{array}$ & $\begin{array}{c}\text { Disease signs } \\
\text { to be recorded }\end{array}$ \\
\hline $15-19 \mathrm{~cm}$ & 100 & External \\
$20-24 \mathrm{~cm}$ & 100 & External \\
$\geq 25 \mathrm{~cm}$ & 50 & External, liver nodules \\
\hline
\end{tabular}


Selection and description of gross lesions. The disease conditions included in the examination were selected according to ICES guidelines (ICES 1989). They have been well described in the literature (Möller \& Anders 1986, Bucke et al. 1993) and can be characterised in terms of their gross appearance and aetiology, where known, as follows:

Lymphocystis (Fig. 1a): A viral disease recognised by the presence of nodules, sometimes creamy white in colour, but occasionally pigmented, in the skin (dermis) of the body and fins. Frequently, nodules are present in the oral cavity.

Epidermal hyperplasia/papilloma (Fig. 1b): Recognised as smooth grey, raised, sometimes spherical areas of epidermis (hyperplasias) or more raised, grey areas, showing pigment or haemorrhage (papilloma). The aetiology is probably viral (Bloch et al. 1986).

Skin ulcerations (Fig. 1c): Usually circular open lesions when acute, but when in the process of healing, the periphery is pigmented and the lesion shows signs of contraction. Healed lesions can be identified as pigmented areas of scale aberration, but were not recorded in this study. The aetiology is probably bacterial (Möller \& Anders 1986).

$\boldsymbol{X}$-cell gill disease (Fig. 1d): Whitened, thickened areas on gill filaments. Fish with this condition were frequently seen to be very lean. This disease is probably caused by a species of Protista (Dawe 1981).

Liver nodule (Fig 1e): Nodular lesions $\geq 2 \mathrm{~mm}$ in diameter, visible on the liver surface. Usually, these nodules are a different colour from the surrounding normal liver. Their aetiology is uncertain, but is probably chemical-related (Malins et al. 1988).

Macroscopic inspection. Prior to external inspection, fish were rinsed with sea water. Both sides of the body surface were carefully examined visually and by hand, the fins were spread and lifted, and the mouth and gill cavities were opened. For internal inspection, the body cavity was opened and the liver dissected out and checked for nodules. The criteria for recording the various disease signs are presented in Table 2.

Internal examination for the presence of liver nodules was performed only with specimens $\geq 25 \mathrm{~cm}$ in length, because such nodules occur much more frequently in large fish than in small ones. During the 2nd survey, smaller liver lesions $(<2 \mathrm{~mm})$ were also recorded. The recording of gross liver nodules and lesions visible to the naked eye facilitated the epidemiological investigation of large numbers of fish. Because of the time and costs involved, it would not have been possible to process such large sample sizes for histological investigation alone.

Although the fish were examined by 2 different groups of observers, one observer participated in both
Table 2. Diagnostic criteria for recording externally visible disease signs and liver nodules. (Modified from ICES 1989)

\begin{tabular}{|ll|}
\hline Disease signs & \multicolumn{1}{c|}{ Criteria for recording } \\
\hline External & \\
-Lymphocystis & More than one surface \\
& nodule \\
-Epidermal hyperplaxia/ & One or more lesions $\geq 2 \mathrm{~mm}$ \\
papilloma & in diameter \\
-Acute/healing skin ulcers & One or more open lesions \\
-X-cell gill disease & One or more filaments \\
& affected \\
Internal & One or more lesions $\geq 2 \mathrm{~mm}$ \\
-Liver nodules & in diameter \\
\hline
\end{tabular}

surveys to ensure standardisation and to minimise inter-observer variability.

Chemical analysis. For chemical analyses, liver and muscle samples from 15 female dab (20-24 cm length) were taken from each haul, and later analysed for concentrations of various micro-contaminants (for details see Cofino et al. 1992).

Histopathological investigation. Any fish with an externally visible disease that presented doubtful diagnosis by the macroscopic screening was preserved in $10 \%$ formol saline for confirmatory histological examination. All liver lesions detected by internal examination in the 1st survey, and selected samples of liver lesions from the 2nd survey, were also preserved. In addition, samples of livers from 5 female dab $(\geq 25 \mathrm{~cm}$ length) from each haul from the 2nd survey were preserved in $10 \%$ formol saline for subsequent histological examination, in order to provide an interpretation of hepatic lesions not detected macroscopically. Samples of skin and muscle tissues were decalcified in $4 \mathrm{~N}$ formic acid. All fixed tissues were processed routinely through to paraffin wax blocks. Sections were cut at $5 \mu \mathrm{m}$ and these were stained with haematoxylin and eosin (H\&E). Additional stains, histochemical and microscopic techniques were applied where necessary to identify or demonstrate specific features.

Data presentation and statistical methods. The data from each survey were analysed separately. The data for the 2 most common diseases were analysed by fitting a linear logistic model. Data on the occurrence of skin ulceration, X-cell gill disease and liver nodules were not analysed with this model because there were insufficient numbers of diseased fish.

Linear logistic model: The linear logistic model (Cox 1970) can be written:

$$
\log (\text { odds })=b_{0}+b_{1} x_{1}+b_{2} x_{2}+\ldots+b_{p} x_{p}
$$

For a disease, the odds are defined as the ratio between the number of fish showing signs of the disease and the number of apparently healthy fish. The 

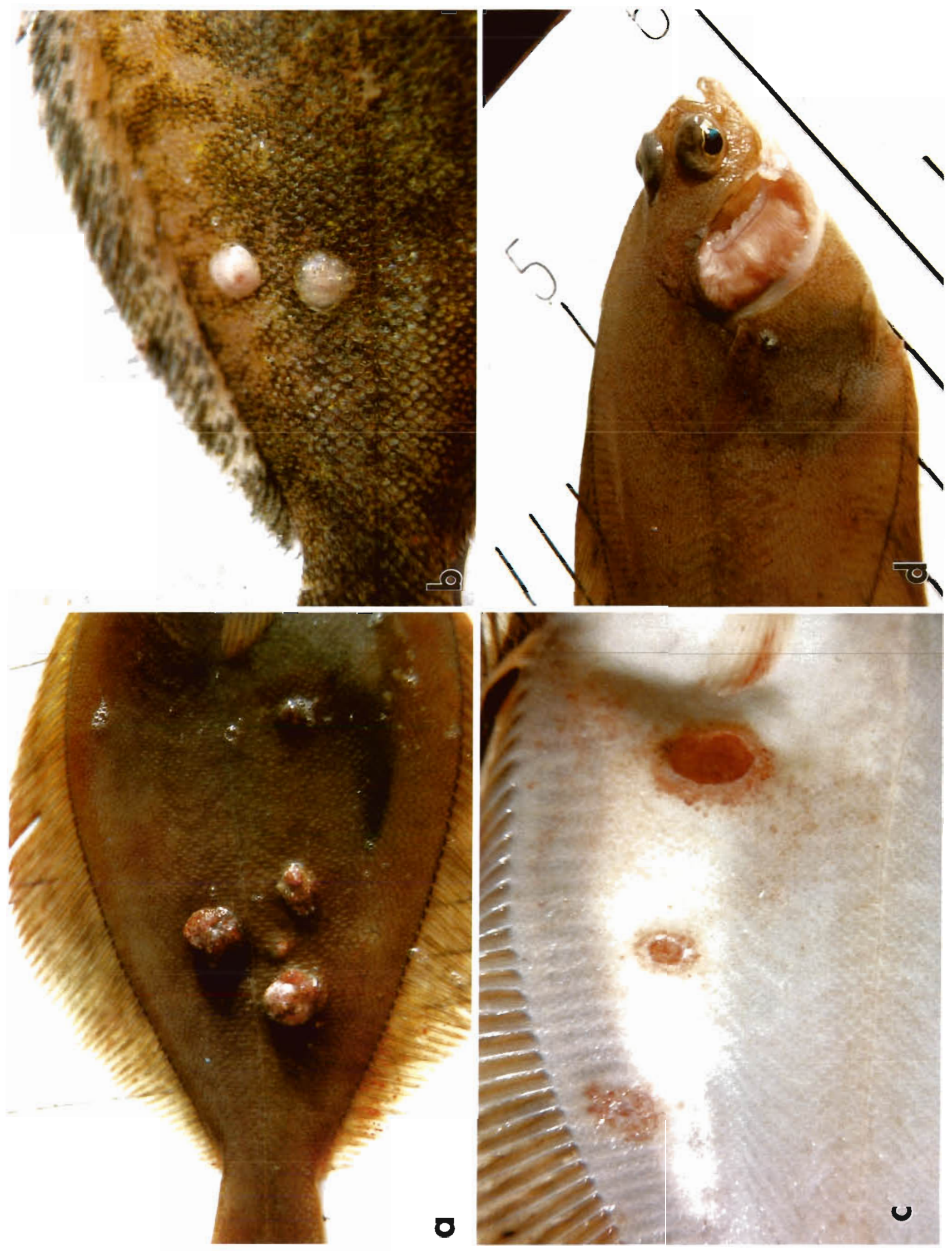


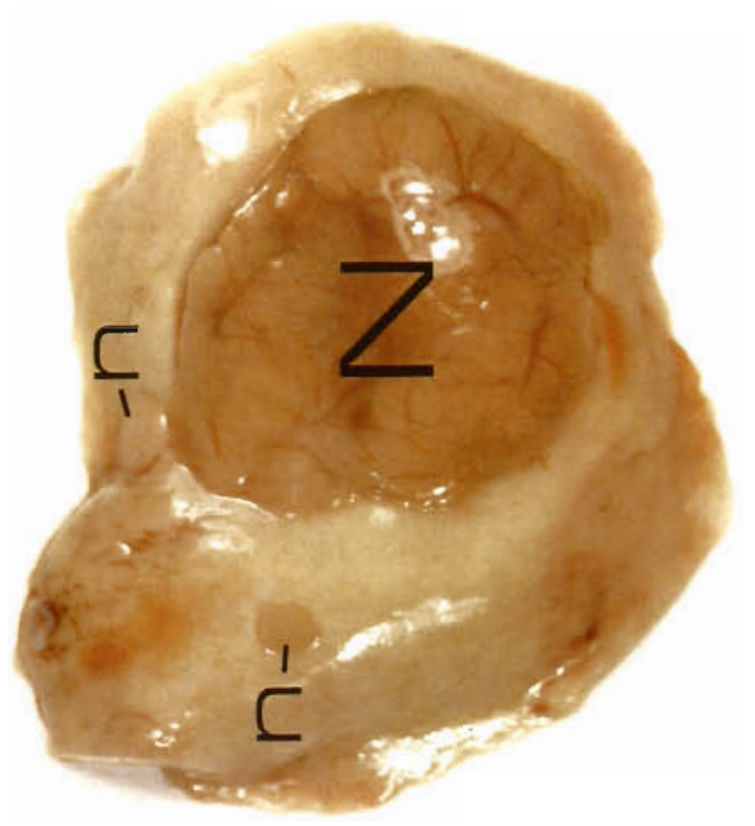

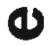

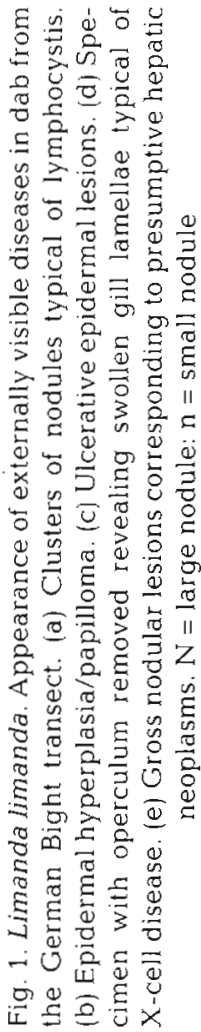

variables $x_{1}, \ldots x_{p}$ can be categorical (e.g. sex), or continuous (e.g. length). The parameter $b_{0}$ represents the log odds of disease risk for a fish with $x_{1}=x_{2}=$ $\ldots=x_{p}=0$, while $\exp \left(b_{k}\right)$ is the fraction by which this risk is increased for every unit increase in $x_{k}$.

Since the diseases were recorded in terms of presence/absence, a binomial error distribution was assumed. However variation between replicates (hauls) was thought to be greater than could be explained by a simple binomial distribution. In other words, disease prevalence was patchy. Hence a parameter $\psi$ (greater than 1) measuring over-dispersion was included. An estimate of $\psi$ was found from the haul-to-haul variation by fitting the full model (all effects and interactions) to the data. It was estimated by $\chi^{2} /(m-p)$, where $\chi^{2}$ is the chi-squared goodness-of-fit statistic, $m$ is the total number of observations, and $p$ is the number of parameters estimated.

The GLIM package (Baker \& Nelder 1978) was used to fit the linear logistic model to the data. This programme uses the deviance as a measure of the goodness-of-fit of a particular model. In order to assess the significance of fitting a term in the model the difference between 2 deviances is calculated, divided by the estimate of $\psi$, and referred to chi-squared tables.

The data were analysed using the explanatory variables sex, size and station. Since there were few males $\geq 25 \mathrm{~cm}$, the 2 largest length categories $(20-24 \mathrm{~cm}$ and $\geq 25 \mathrm{~cm}$ ) were pooled prior to analysis.

There are no clear guidelines available for deciding on the 'best' model (McCullagh \& Nelder 1989). Hence all main effects (sex, station and length) were included in order to facilitate comparisons between studies. Any interaction terms were included if they were statistically significant at the $5 \%$ level.

Odds ratios have been used as summary measures because they are easy to interpret. They have been calculated relative to the following 'baselines': Stn 3, female, and small size. The estimated odds for each station are divided by the estimated odds at Stn 3 to give the odds ratio. The $95 \%$ confidence limits are given for odds ratios involving sex and size (these confidence intervals are correct even though the significance testing framework used to choose a model has broken down). If these confidence intervals do not include 1, there exists a significant difference between sexes or sizes at the $5 \%$ level. However no confidence intervais are given for the odds ratios involving stations. To do so would be misleading because we would be presenting 5 odds ratios out of a possible 15 (the number of pairwise comparisons of 6 stations). Instead, only the significance level for the global test of station differences is given.

The inter-survey variation was found by pooling over hauls and fitting the full linear logistic model (all main 
effects and interactions) to the data from both surveys, and calculating a value of $\psi$ as before.

Length-age model: Previous studies have shown that the von Bertalanfy model can provide a useful fit to data relating fish length to age. For the von Bertalanffy model we have:

$$
\text { length }=b_{0}\left(1-b_{1} \exp \left[-b_{2} \text { Age }\right]\right)
$$

The parameter $b_{0}$ is an estimate of the maximum size. Since some fish are larger than $b_{0}$ their age cannot be determined from this equation. However plots of age $(y)$ against length $(x)$ suggested that a linear regression, fitted using weighted least squares $\left(w_{1}=\right.$ $1 / x_{i}^{2} ; x_{i}=$ length of fish $i$ ), could be used. Hence separate regression lines were fitted to the 12 length-age data sets ( 6 stations $\times 2$ surveys).

The fitted lines were used to estimate age from length for the samples used to investigate external diseases. Fish were then classified as young ( $\leq 4 \mathrm{yr}$ ) or old $(>4 \mathrm{yr})$. A linear logistic analysis was then carried out on lymphocystis and epidermal hyperplasia/papilloma using the 3 explanatory variables sex, age and station.

The variation in the predicted value of age for a given length has been ignored. This will tend to overemphasise the importance of age in the linear logistic model. Furthermore it has been assumed that the growth rates of healthy and diseased dab are the same. Such an assumption for the 2 diseases in question (lymphocystis and epidermal hyperplasia/papilloma) is considered justified (Dethlefsen et al. 1987).

Other statistical analyses: Associations between the different diseases in individual fish were investigated by comparing the presence or absence of internal disease to the presence or absence of each of the 4 external diseases, and by comparing the 4 external diseases pairwise, using contingency table analyses. The chi-square goodness-of-fit statistic was used to assess the degree of association.

For female fish (length $20-24 \mathrm{~cm}$ ) somatic liver index, somatic gonad index and condition factor were compared across stations using a 1-way analysis of variance. Where statistically significant differences were found, correlation coefficients between the mean value and log-disease odds at each station were calculated.

For the same group of fish correlation coefficients between log-disease odds and contaminant concentrations in the liver, using the mean values at each station, were calculated. Since considerable interhaul variation was found in the contaminant data, particularly for PCBs (Cofino et al. 1992), correlation coefficients were also calculated using data for individual hauls.

\section{RESULTS}

\section{Catch data}

The total number of dab examined for external disease was 7565 (all length classes combined): 4969 during the 1 st survey and 2596 during the 2 nd survey. The number of hauls at each station varied from 2 to 6 depending on the size of the catches and the fishing conditions (Table 3 ). It was not possible to comply with the stratified sampling design and minimal sample sizes as

Table 3. Limanda limanda. Number of dab inspected for externally visible diseases according to length class and sex at each station, together with the number of hauls. F: females; $M$ : males

\begin{tabular}{|c|c|c|c|c|c|c|c|c|}
\hline & \multirow[t]{2}{*}{$\begin{array}{l}\text { No. of } \\
\text { hauls }\end{array}$} & \multicolumn{2}{|c|}{$\begin{array}{l}\text { Length class } \\
15-19 \mathrm{~cm}\end{array}$} & \multicolumn{2}{|c|}{$\begin{array}{l}\text { Length class } \\
20-24 \mathrm{~cm}\end{array}$} & \multicolumn{2}{|c|}{$\begin{array}{l}\text { Length class } \\
\quad \geq 25 \mathrm{~cm}\end{array}$} & \multirow[t]{2}{*}{ Total } \\
\hline & & F & M & F & $M$ & $F$ & $M$ & \\
\hline \multicolumn{9}{|l|}{ Survey 1} \\
\hline $\operatorname{Stn} 3$ & 4 & 32 & 6 & 100 & 2 & 46 & 0 & 186 \\
\hline Stn 5 & 4 & 234 & 264 & 362 & 88 & 225 & 2 & 1175 \\
\hline $\operatorname{Stn} 6$ & 3 & 321 & 179 & 450 & 50 & 114 & 4 & 1118 \\
\hline $\operatorname{Stn} 7$ & 3 & 130 & 169 & 149 & 75 & 38 & 1 & 562 \\
\hline $\operatorname{Stn} 8$ & 3 & 139 & 161 & 231 & 69 & 85 & 1 & 686 \\
\hline $\sin 9$ & 5 & 221 & 279 & 380 & 125 & 226 & 11 & 1242 \\
\hline Total & 22 & 1077 & 1058 & 1672 & 409 & 734 & 19 & 4969 \\
\hline \multicolumn{9}{|c|}{ Survey 2} \\
\hline $\operatorname{Stn} 3$ & 4 & 90 & 32 & 104 & 8 & 30 & 1 & 265 \\
\hline $\operatorname{Stn} 5$ & 2 & 70 & 130 & 132 & 61 & 96 & 4 & 493 \\
\hline $\operatorname{Stn} 6$ & 2 & 78 & 122 & 157 & 51 & 82 & 1 & 491 \\
\hline $\operatorname{Stn} 7$ & 2 & 70 & 130 & 117 & 61 & 23 & 2 & 403 \\
\hline $\operatorname{Stn} 8$ & 3 & 113 & 187 & 119 & 140 & 27 & 1 & 587 \\
\hline $\operatorname{Stn} 9$ & 2 & 59 & 94 & 93 & 65 & 44 & 2 & 357 \\
\hline Total & 1.5 & 480 & 695 & 722 & 386 & 734 & 11 & 2596 \\
\hline
\end{tabular}


Table 4. Limanda limanda. Overall observed prevalence of gross diseases in dab

\begin{tabular}{|c|c|c|c|c|c|c|}
\hline \multirow{2}{*}{ Disease } & \multicolumn{2}{|c|}{ 1st survey } & \multicolumn{2}{|c|}{ 2nd survey } & \multicolumn{2}{|c|}{ Total } \\
\hline & $\%$ & $\mathrm{n}$ & $\%$ & $\mathrm{n}$ & $\%$ & $\mathrm{n}$ \\
\hline Lymphocystis & 9.8 & $(487)$ & 11.9 & $(308)$ & 10.5 & $(795)$ \\
\hline Epidermal hyperplasia/papilloma & 5.8 & $(287)$ & 7.1 & $(185)$ & 6.2 & $(472)$ \\
\hline Acute and healing skin ulcers & 1.8 & $(89)$ & 1.5 & $(40)$ & 1.7 & (129) \\
\hline$X$-cell gill disease & 0.4 & (21) & 0.5 & (12) & 0.4 & $(33)$ \\
\hline Total & & $(4969)$ & & (2596) & & $(7565)$ \\
\hline
\end{tabular}

\section{LYMPHOCYSTIS}

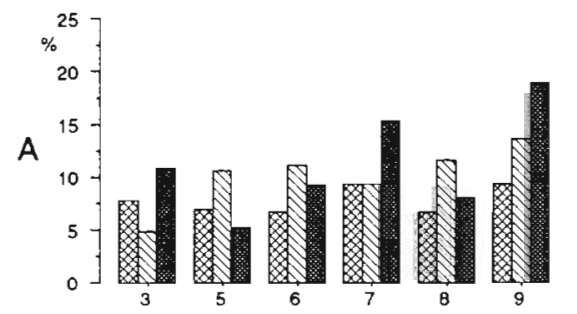

EPIDERMAL HYPERPLASIAVPAPILLOMA

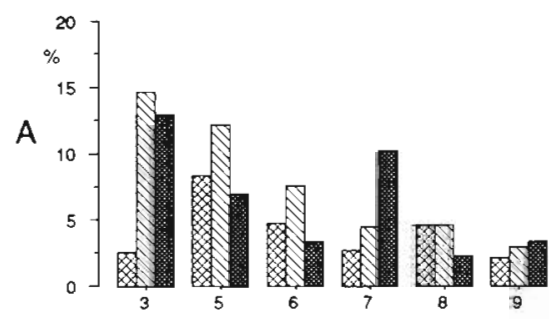

SKIN ULCERATION

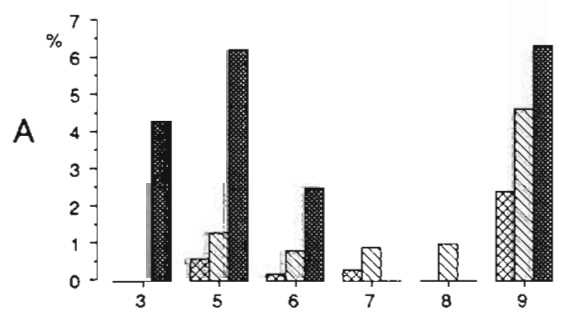

$X$-CEL GILL LESION
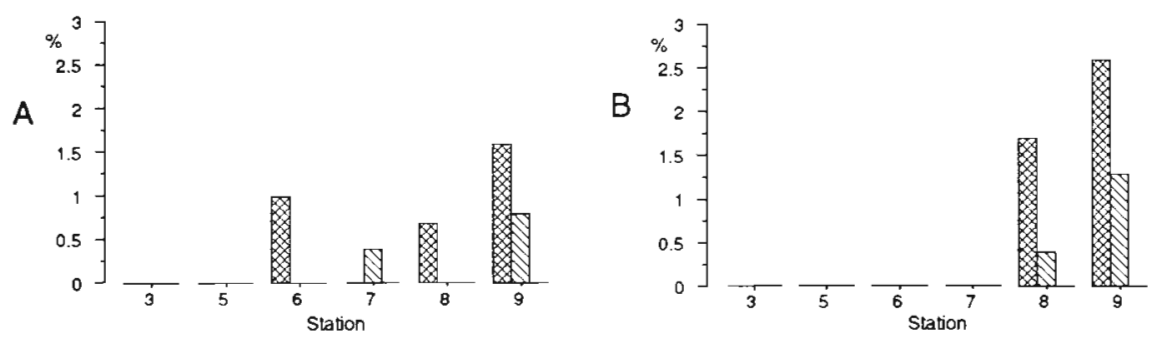

冈15.19cm $\quad \nabla 20.24 \mathrm{~cm} \quad \geqslant 25 \mathrm{~cm}$

Fig. 2. Limanda limanda. Crude prevalence data of the 4 externally visible diseases in dab plotted by length class for each station (pooled hauls). (A) 1st survey, (B) 2nd survey recommended by ICES (Table 2) for each station. The target sample size (100 fish per haul) was usually reached for the $15-19 \mathrm{~cm}$ and $20-24 \mathrm{~cm}$ length classes. However, it was not always possible to collect sufficient numbers of fish from the large length class $(\geq 25 \mathrm{~cm}$; 50 fish per haul) (Table 3). Consequently, the total number of fish inspected for internal disease was relatively low. Moreover, since very few large male dab were caught, they were excluded from any further analysis of the internal disease data.

\section{Observed disease patterns of gross lesions}

Externally visible diseases. Histological examination of gross lesions showed that in several instances doubtful cases of lymphocystis proved histologically to be epidermal hyperplasia/papilloma. The necessary corrections were incorporated in the final data set.

The most common disease recorded was lymphocystis $110.5 \%$ of all the fish examined), followed by epidermal hyperplasia/papilloma (6.2\%). Skin ulcerations and $\mathrm{X}$-cell gill disease were less common $(1.7 \%$ and $0.4 \%$ respectively; Table 4).

In Fig. 2, the spatial distributions of the 4 external diseases 
Table 5. Limanda limanda. Results of histological examination of livers from female dab (length $\geq 25 \mathrm{~cm}$ ), showing gross lesions $\mathrm{n}=$ number examined; ne = number showing lesions; $N A D=$ no abnormalities detected; for further details see text

\begin{tabular}{|c|c|c|c|c|c|c|c|c|c|c|}
\hline Station & $\begin{array}{l}\text { No. of } \\
\text { hauls }\end{array}$ & $\mathrm{n}$ & ne & $(\%)$ & NAD & $\begin{array}{l}\text { Clear-cell } \\
\text { foci }\end{array}$ & $\begin{array}{l}\text { Basophilic } \\
\text { foci }\end{array}$ & $\begin{array}{l}\text { Hepatocellular } \\
\text { adenoma }\end{array}$ & Cysts & Other \\
\hline 3 & 6 & 46 & 3 & (6.5) & 0 & 0 & 0 & 2 & 0 & 1 \\
\hline 5 & 4 & 177 & 11 & $(6.2)$ & 0 & 5 & 0 & 3 & 1 & 2 \\
\hline 6 & 5 & 114 & 1 & $(0.9)$ & 0 & 0 & 0 & 1 & 0 & 0 \\
\hline 7 & 3 & 38 & 1 & (2.6) & 0 & 0 & 0 & 0 & 1 & 0 \\
\hline 8 & 3 & 85 & 9 & $(10.6)$ & 2 & 2 & 1 & 3 & 1 & 0 \\
\hline 9 & 5 & 226 & 15 & $(6.6)$ & 1 & 1 & 2 & 3 & 3 & 5 \\
\hline Total & 26 & 686 & 40 & $(5.8)$ & $3(0.4)$ & $8(1.2)$ & $3(0.4)$ & $12(1.7)$ & $6(0.9)$ & $8(1.2)$ \\
\hline
\end{tabular}

are presented separately for the 2 surveys. The prevalences of the 4 diseases increased with size, except for the prevalence of $X$-cell gill disease which was highest in the small dab and fell to zero in large dab. Furthermore it can be seen that the prevalence of epidermal hyperplasia/papilloma decreased with distance offshore, whereas lymphocystis showed the opposite trend, with highest prevalences at the outermost station (Stn 9). The prevalence of skin ulcerations showed no clear spatial trend, except for notably higher values at the outermost station (Stn 9) relative to Stns $7 \& 8$. The occurrence of X-cell gill disease was limited to Stns 6 to 9

Liver nodules. During the 1st survey, a total of 686 female dab $\geq 25 \mathrm{~cm}$ were examined for liver changes. In total, 40 nodular lesions (Fig. 1e) were observed which were diagnosed as belonging to the following categories:

- clear-cell foci ( 8 cases; $20 \%$ ),

basophilic foci ( 3 cases; $7.5 \%$ ),

- hepatocellular adenoma (12 cases; $30 \%$ ),

- cysts (6 cases; $15 \%$ ),

- 'other' which included parasitic lesions, inflammation, peliosis and necrosis ( 8 cases; $20 \%$ ), and

- 'unconfirmed' or 'no abnormalities detected' ( 3 cases; $7.5 \%$ ).

The prevalences of neoplasia (hepatocellular adenoma) and foci of cellular alteration (clear-cell and basophilic foci) were low, and together with the small sample sizes (Table 5), do not allow a realistic evaluation of spatial trends

A clear-cell focus (storage cell change) was diagnosed when a discrete aggregate of hepatocytes showed increase in size and decrease in staining due to storage of fat or glycogen (Fig. 3a).

A basophilic focus was seen to consist of aggregates of hepatocytes with distinct tinctorial changes from those in the surrounding parenchyma, not as a result of increased storage products (Fig. 3b). Hepatic foci were mostly circular in appearance, but the actual hepatocyte cords in the focus were seen to integrate with the surrounding hepatic parenchyma and there was no evidence of peripheral hepatocyte compression.

Hepatocellular adenomas were also usually nodular in appearance (Fig. 3c). There were clearly defined borders to the nodules and the surrounding hepatocytes showed definite compression. Hepatocytes within the adenomas appeared mostly normal, but did not merge with the surrounding liver. In a few instances there was evidence of hyperaemia and necrosis (Fig. 3d). Hepatocellular carcinoma was not identified in these samples.

Other histological changes detected included cysts (Fig. 3e), granulomas, fibrosis, and necrosis probably as a result of parasitic disease. In several livers there was clear evidence of parasitic infestations by nematodes (Fig. 3f), and Glugea sp. xenomas (Fig. 3g), the last especially in samples from $\operatorname{Stn} 9$.

On the 2nd survey, more attention was paid to the characterisation of the smaller nodules and pigmented lesions observed in dab livers during postmortem examination. Therefore, in addition to grossly visible nodules ( $\geq 2 \mathrm{~mm}$ in diameter), smaller nodules and pigmented lesions ( $<2 \mathrm{~mm}$ in diameter) from the liver of the same fish were subjected to histological examination. The spatial distribution of these smaller lesions on the German Bight transect revealed a decreasing prevalence with increasing distance from the coast. By histological examination of subsamples of the small lesions, about half of them were confirmed as foci of cellular alteration. The hepatic lesions $\geq 2 \mathrm{~mm}$ from the 2 nd survey were broadly similar to those from the 1st survey, except that there were 2 cases of hepatocellular cholangioma. These neoplasms were seen as clear, defined nodular areas within the hepatic parenchyma. They contained distinct, densely stained cuboidal cells which had formed tubular-cystic structures interpreted as dilated biliary ducts (Fig. 3h).

A further histological diagnosis achieved during this survey was of the small white spots frequently seen on the surface of dab livers during post-mortem examina- 
tion. These lesions appeared under the microscope to be clusters of ghost-like cells and debris on the peritoneal surface of the liver This was confirmed to be calcified material.

Further histological investigations

In large female fish from the 2nd survey which did not show gross lesions, significant histological abnormalities in the liver were related mostly to fat storage in hepatocytes and to foci of cellular alteration (clearcell and basophilic foci) (Table 6). These occurred in 14 of 110 livers examined (12.7\%). No spatial pattern could be established due to the small numbers of fish examined. The absence of liver neoplasia from these apparently healthy livers underlines the usefulness of the gross examination provided this is followed by histological confirmation.

\section{Associations between diseases}

There was no evidence of any association between the presence or absence of internal diseases (neoplasia and foci of cellular alteration) and the 4 external diseases in individual fish. There was no evidence of any association among the 4 external diseases.

Linear logistic analysis

Length, sex and station as explanatory variables. Of the 2 diseases analysed, only lymphocystis data from the 2 nd survey gave a significant amount of over-dispersion $(\psi=1.85, \mathrm{p}<0.05)$, indicating significant inter-haul variation, and hence the presence of patchiness in the distribution of the disease.
Fig. 3. Limanda limanda. Histological sections of gross nodular lesions in livers of dab from the German Bight transect. (a) Clearcell focus (storage cell change) with cytoplasmic vacuoles suggestive of lipid storage. H\&E, $\times 150$. (b) Basophilic focus. Note the decrease in storage products and the lack of compression. Upper $\left(b_{1}\right)$ : H\&E, $\times 80$; lower $\left(b_{2}\right)$ : H\&E, $\times 260$. (c) Hepatocellular adenoma. Note the different cytology and architecture of the tumour and the compression of adjacent parenchyma. H\&E, $\times 40$. (d) Hepatocellular adenoma with cystic/necrotic centre. H\&E, $\times 40$. (e) Multiple cysts causing space-occupying mass. H\&E, $\times 40$. (f) Superficial parasitic cyst containing cross-sectioned calcified remnants of a nematode. H\&E, $\times 40$. (g) Parasitic cyst (Glugea sp.) protruding on the surface. $\mathrm{H} \& \mathrm{E}, \times 100$. (h) Cholangioma. H\&E, $\times 150$

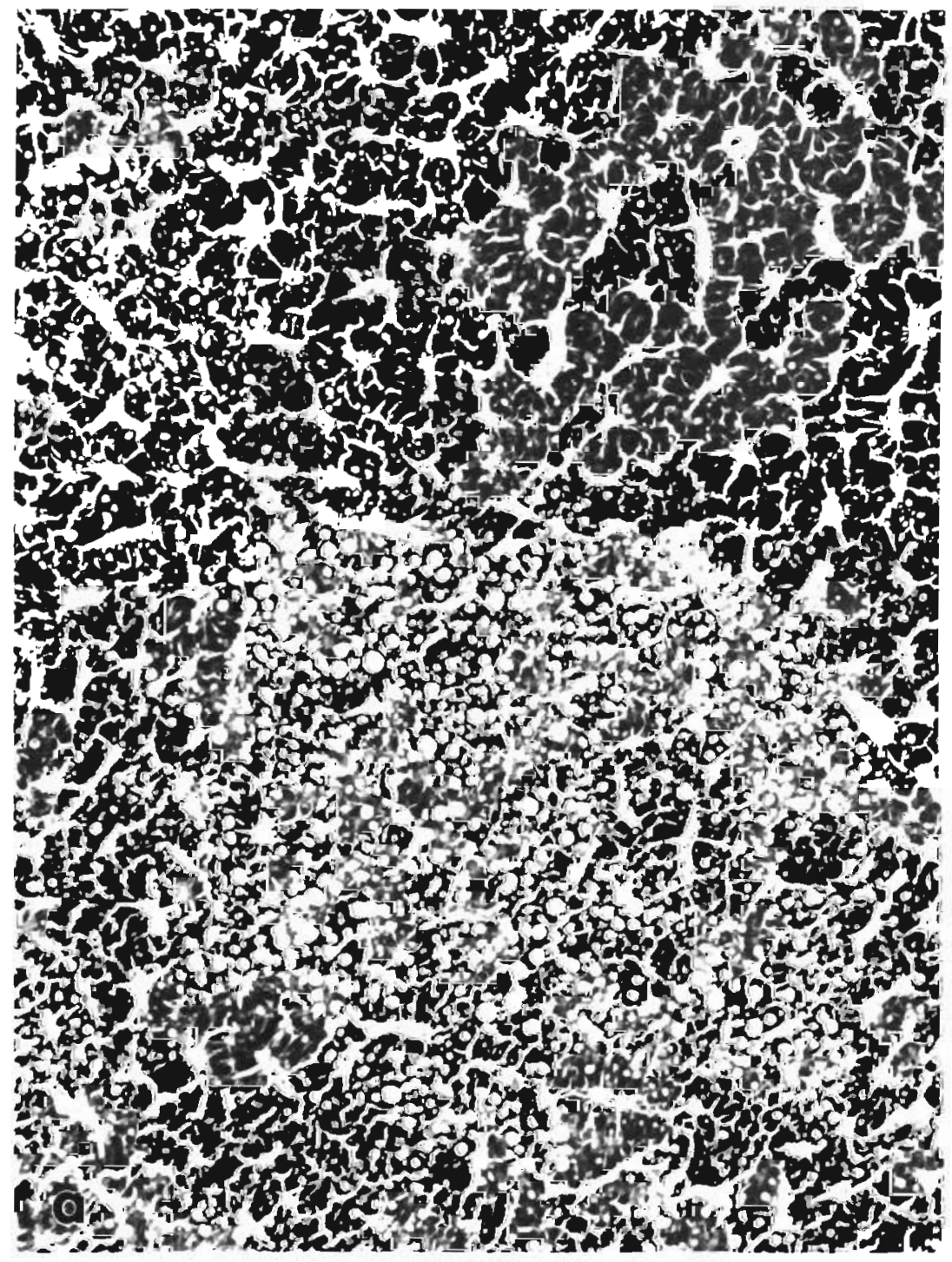

Fig. 3 continued on following pages) 


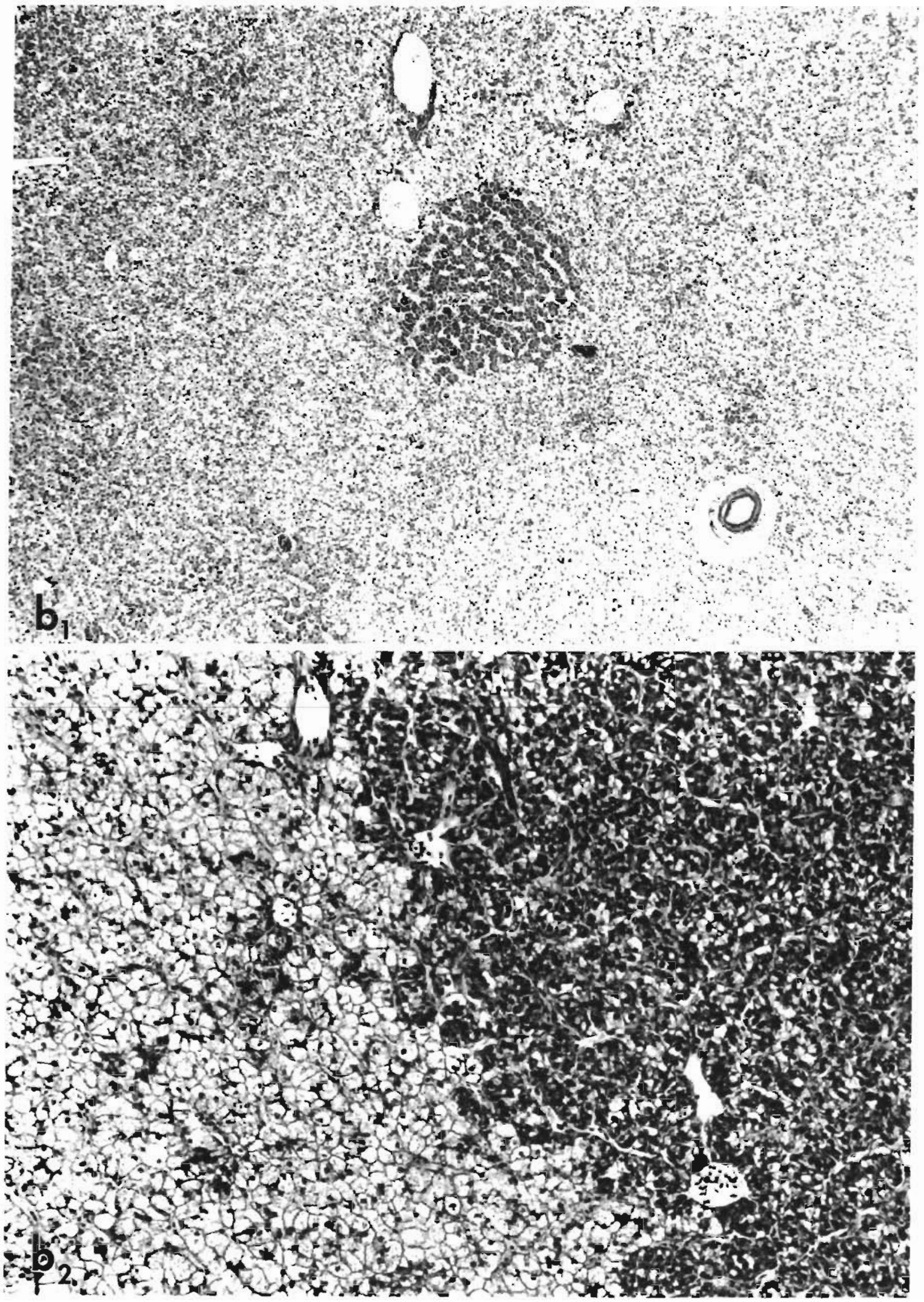

Fig 3 (continued) 


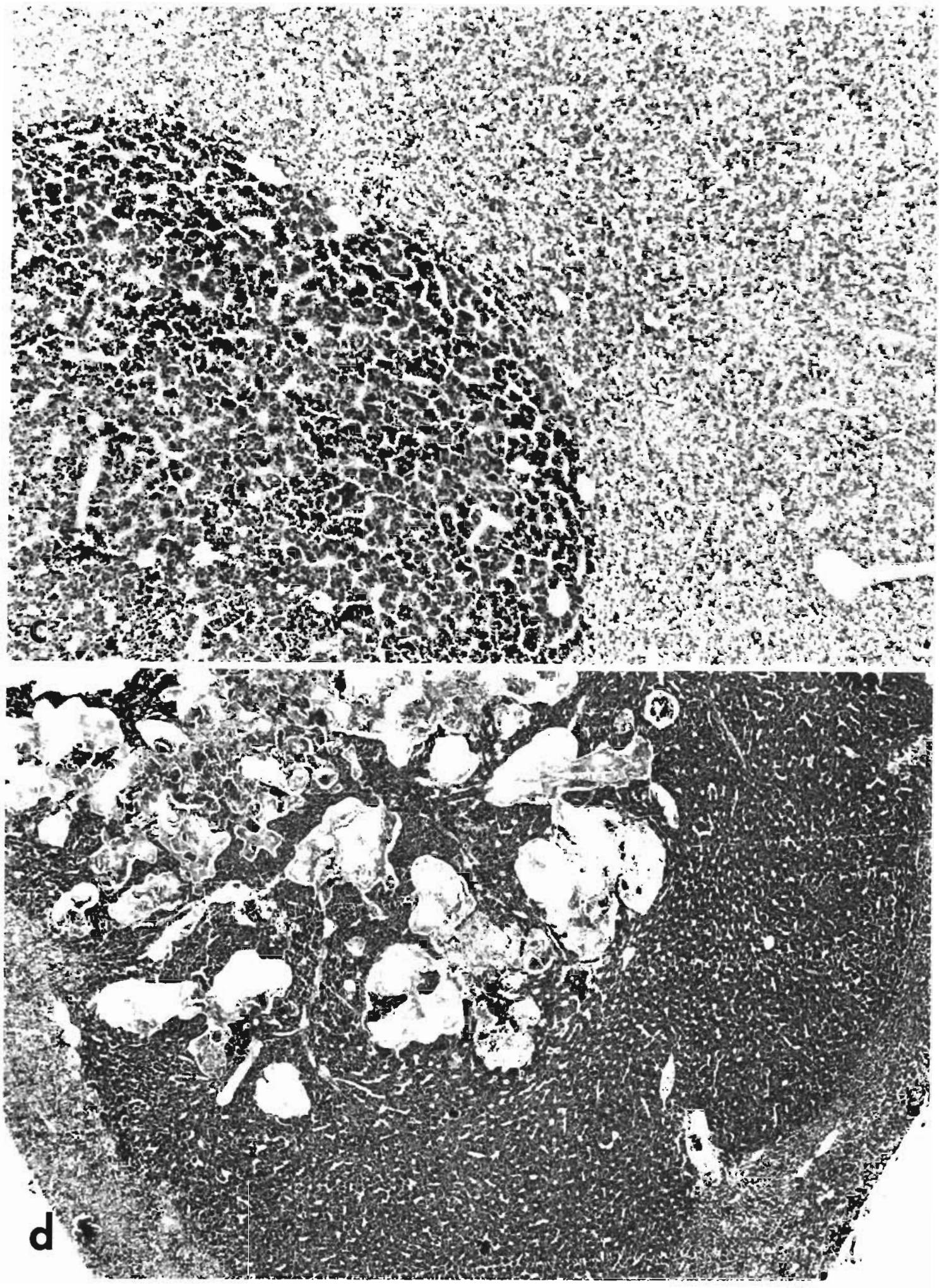

Fig. 3 (continued) 

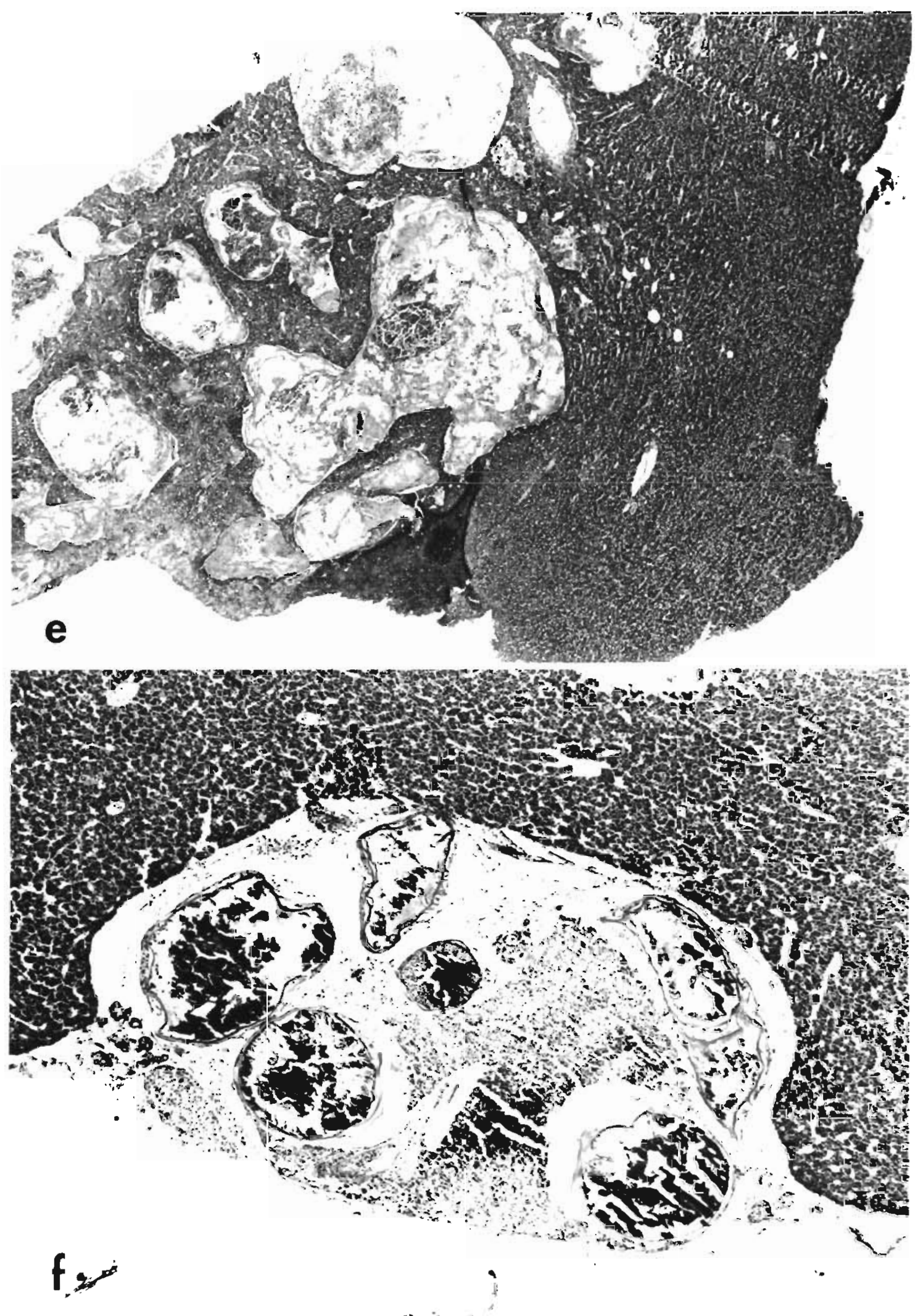


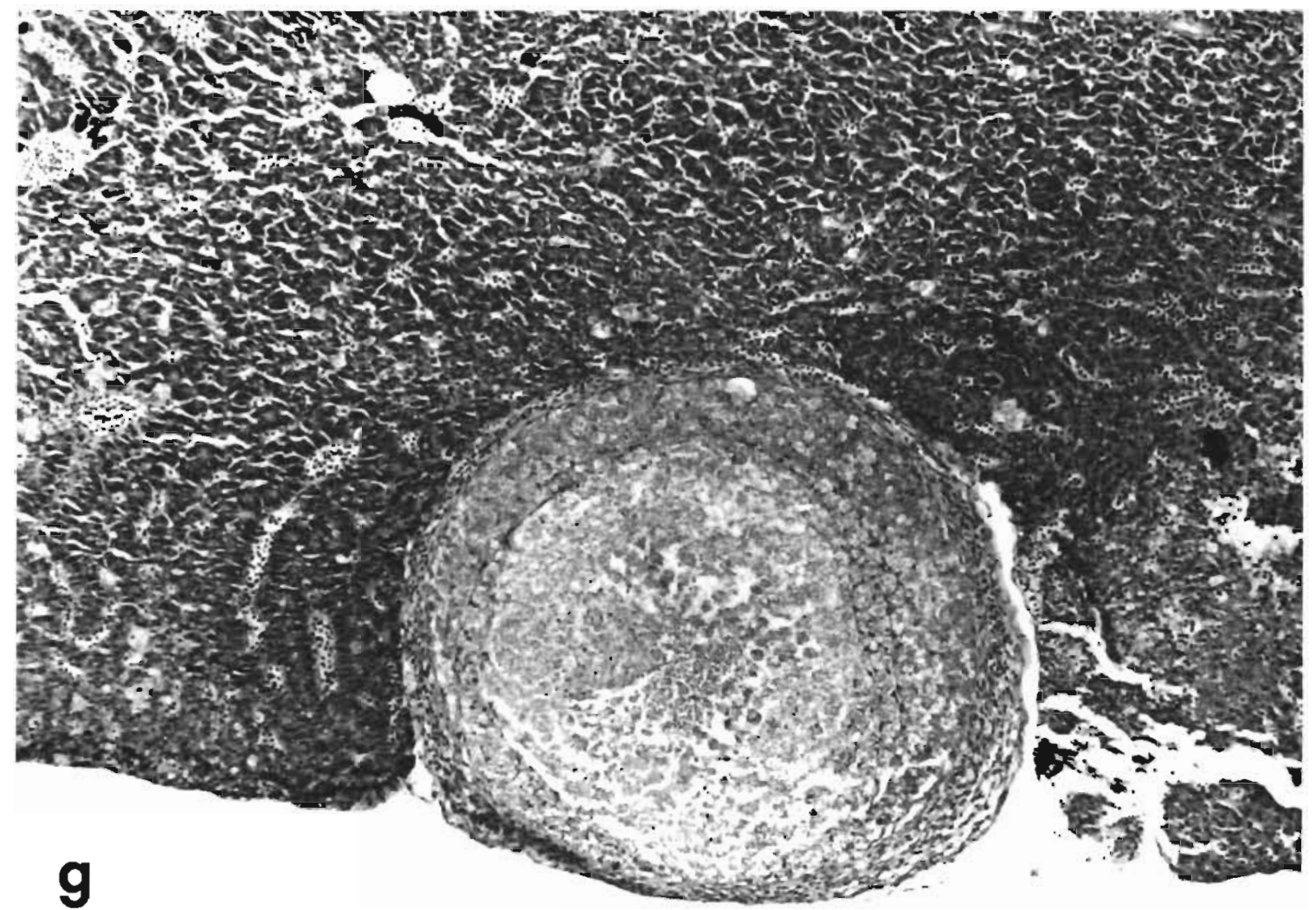

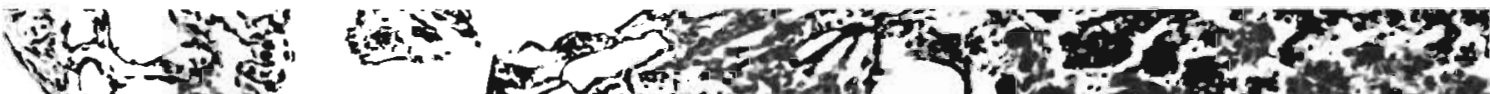

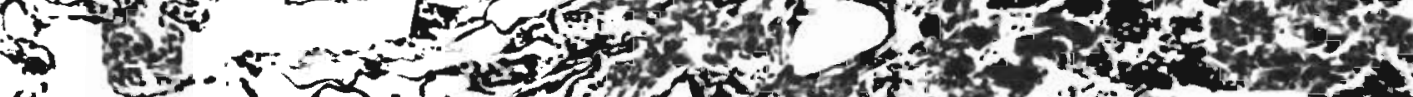
Hat

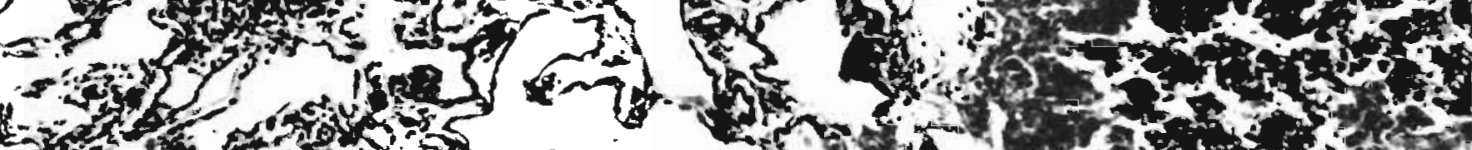

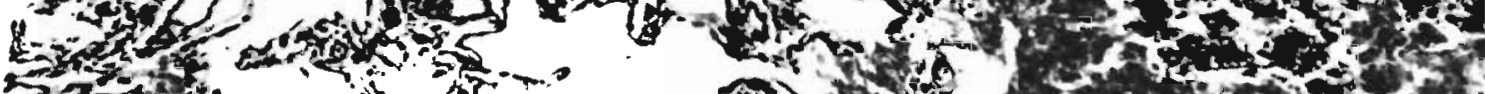

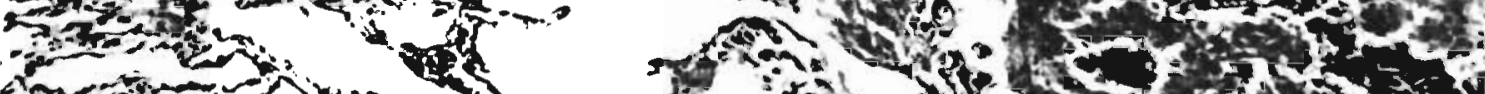

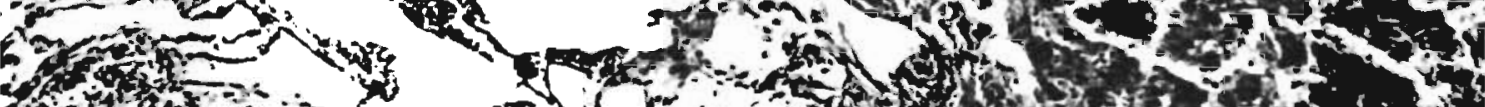

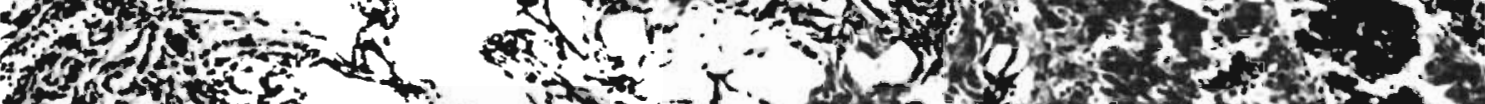
70 s.

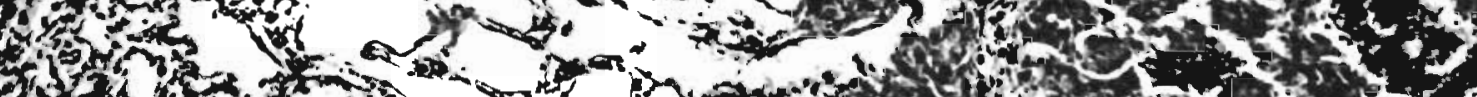
col 4.

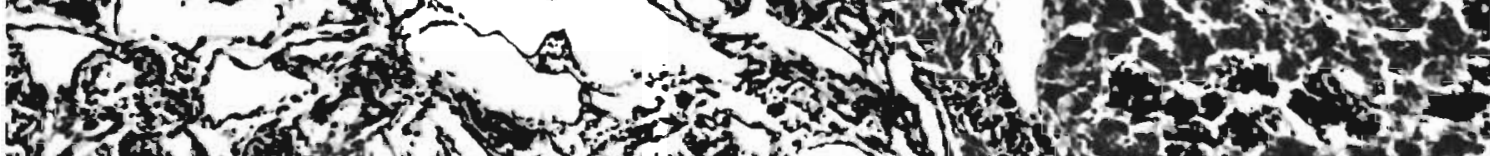

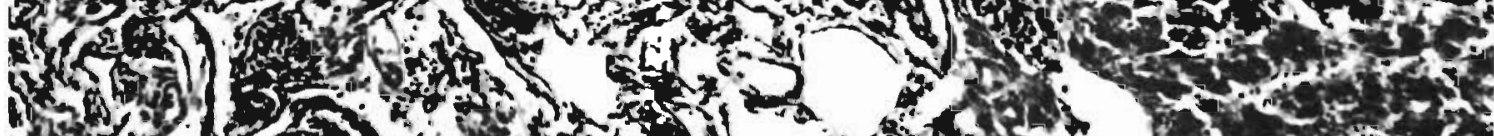
40 (2) -14. 
Table 6. Limanda limanda. Results of histological examination of livers from female dab (length 20-24 cm), not showing gross lesions. $\mathrm{n}=$ number examined ; WN $=$ within normal limits; other $=$ minor necrosis, parasites, etc.

\begin{tabular}{|cccccccccc|}
\hline Station & $\begin{array}{c}\text { No. of } \\
\text { hauls }\end{array}$ & $\mathrm{n}$ & WNL & $\begin{array}{c}\text { Clear-cell } \\
\text { foci }\end{array}$ & $\begin{array}{c}\text { Basophilic } \\
\text { foci }\end{array}$ & $\begin{array}{c}\text { Hepatocellular } \\
\text { adenoma }\end{array}$ & Cysts & Peliosis & Other \\
\hline 3 & 4 & 20 & 12 & 3 & 2 & 0 & 1 & 1 & 1 \\
5 & 4 & 20 & 18 & 2 & 0 & 0 & 0 & 0 & 0 \\
6 & 3 & 15 & 12 & 2 & 1 & 0 & 0 & 0 \\
7 & 3 & 15 & 13 & 0 & 0 & 0 & 0 & 1 \\
8 & 3 & 15 & 9 & 2 & 1 & 0 & 0 & 0 \\
9 & 5 & 25 & 23 & 0 & 1 & $0(0.0)$ & $3(8.2)$ & $2(1.8)$ \\
Total & 22 & 110 & $87(79.0)$ & $9(8.2)$ & $5(4.5)$ & $4(3.6)$ \\
\hline
\end{tabular}

The estimated odds ratios for the 2 diseases at each station are given in Table 7 . Significant differences between stations were found for lymphocystis (1st survey only; $\mathrm{p}<0.01$ ) and epidermal hyperplasia/papilloma (both surveys; $p<0.01$ ). In general terms, the prevalence of lymphocystis was found to increase from Stns 3 to 9, while the prevalence of epidermal hyperplasia/ papilloma was found to decrease in the same direction.

Significant differences were found between sexes and length groups for lymphocystis (1st survey only;

Table 7 Limanda limanda. Odds ratios for lymphocystis (Ly) and epidermal hyperplasia/papilloma (EP) in dab at each station during the 1 st and 2 nd surveys (odds ratios adjusted for sex and length)

\begin{tabular}{|lcccc|}
\hline Effect & Ly (1st) & Ly (2nd) & EP (1st) & EP (2nd) \\
\hline Stn 3 & 1.00 & 1.00 & 1.00 & 1.00 \\
Stn 5 & 1.20 & 1.38 & 0.92 & 1.35 \\
Stn 6 & 1.41 & 1.80 & 0.53 & 0.74 \\
Stn 7 & 1.49 & 1.88 & 0.39 & 0.67 \\
$\operatorname{Stn} 8$ & 1.35 & 1.61 & 0.41 & 0.27 \\
Stn 9 & 1.99 & 1.95 & 0.25 & 0.38 \\
\hline
\end{tabular}

$p<0.01)$. Significant differences were found between sexes for epidermal hyperplasia/papilloma (2nd survey only; $\mathrm{p}<0.01$ ). A significant interaction between sex and length fand hence significant effects of sex and length) occurred for epidermal hyperplasia/papilloma. (1st survey only; $\mathrm{p}<0.01$ ) (Table 8 ).

Age, sex and station as explanatory variables. The length-age plots at each station which are used to estimate age from length are given in Fig. 4. Tables $9 \& 10$ give the analysis of data on external disease using age instead of length. Significant variation $(p<0.01)$ among stations was found for lymphocystis (1st survey only) and epidermal hyperplasia/papilloma (both surveys) (Table 9). Significant differences between sexes were found for epidermal hyperplasia/papilloma, and between old and young fish for lymphocystis (Table 10).

Using age instead of length did not substantially alter the estimated odds ratios for the stations, given in Table 7 .

Inter-survey variation. Only epidermal hyperplasia/papilloma showed significant survey-to-survey variation $(\psi=1.65 ; \mathrm{p}<0.05)$. This could be due to inter-

Table 8. Limanda limanda. Odds ratios (with $95 \%$ confidence limits) for lymphocystis (Ly) and epidermal hyperplasia/papilloma (EP) in male (M)/female (F) and large/small dab during the 1st and 2nd surveys (odds ratios adjusted for station/length and station/sex)

\begin{tabular}{|c|c|c|c|c|}
\hline Effect & Ly $(1 s t)$ & Ly $(2 n d)$ & $E P(1 s t)$ & $\mathrm{EP}(2 \mathrm{nd})$ \\
\hline $\mathrm{M} / \mathrm{F}$ & $\begin{array}{c}1.40 \\
(1.12-1.74)\end{array}$ & $\begin{array}{c}1.07 \\
(0.76-1.52)\end{array}$ & - & $\begin{array}{c}0.57 \\
(0.39-0.83)\end{array}$ \\
\hline Large/small & $\begin{array}{c}1.70 \\
(1.37-2.10)\end{array}$ & $\begin{array}{c}1.23 \\
(0.88-1.73)\end{array}$ & - & $\begin{array}{c}1.36 \\
(0.97-1.90)\end{array}$ \\
\hline Small $\mathrm{M} / \mathrm{small} \mathrm{F}$ & - & - & $\begin{array}{c}1.07 \\
(0.71-1.60)\end{array}$ & - \\
\hline Large $F / s m a l l ~ F$ & - & - & $\begin{array}{c}1.61 \\
(1.17-2.23)\end{array}$ & - \\
\hline Large $M /$ large $F$ & - & - & $\begin{array}{c}0.27 \\
(0.13-0.56)\end{array}$ & - \\
\hline Large $\mathrm{M} / \mathrm{small} \mathrm{M}$ & - & - & $\begin{array}{c}0.41 \\
(0.19-0.87)\end{array}$ & - \\
\hline
\end{tabular}



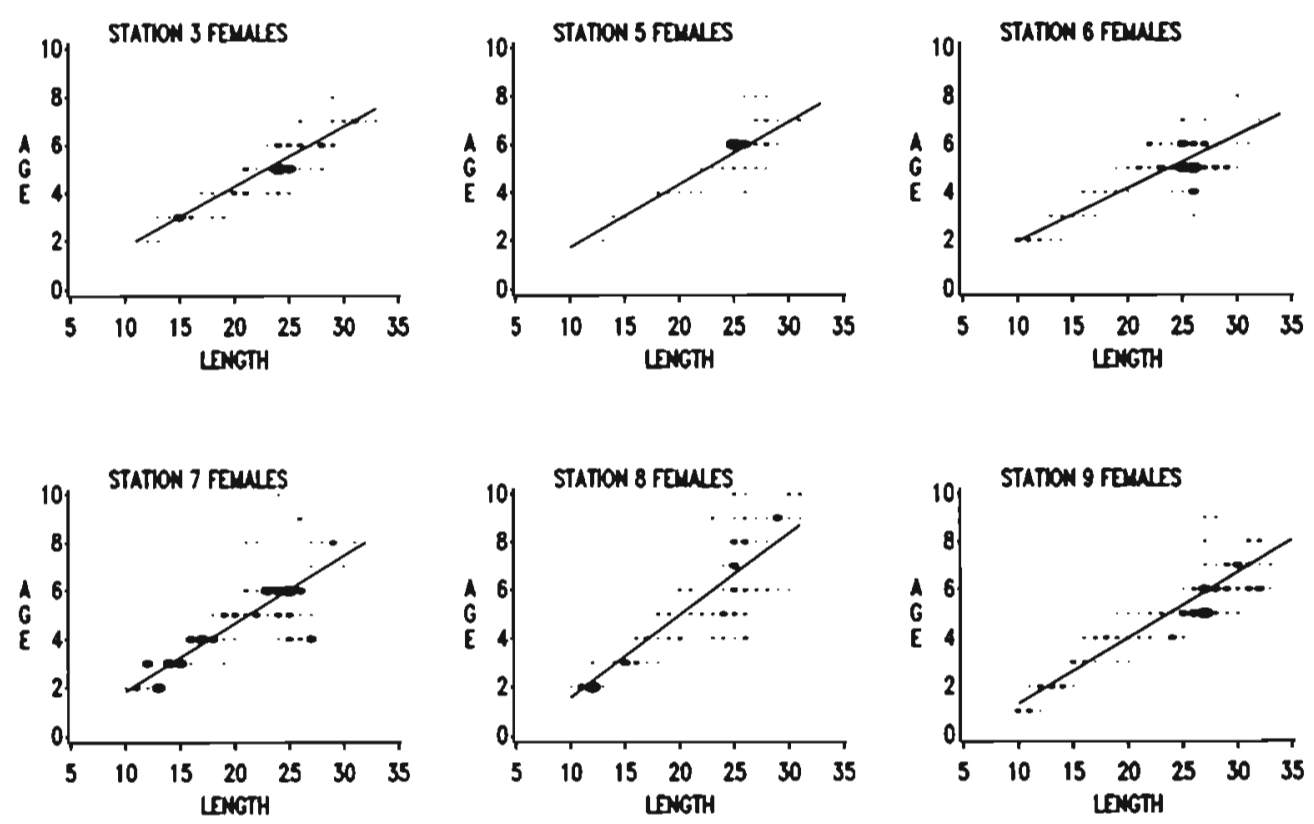

Fig. 4 Limanda limanda. Scatter plots and fitted lines for age-length data in dab plotted by sex and station. Diameters of plotted points are proportional to the number of fish in each mm length
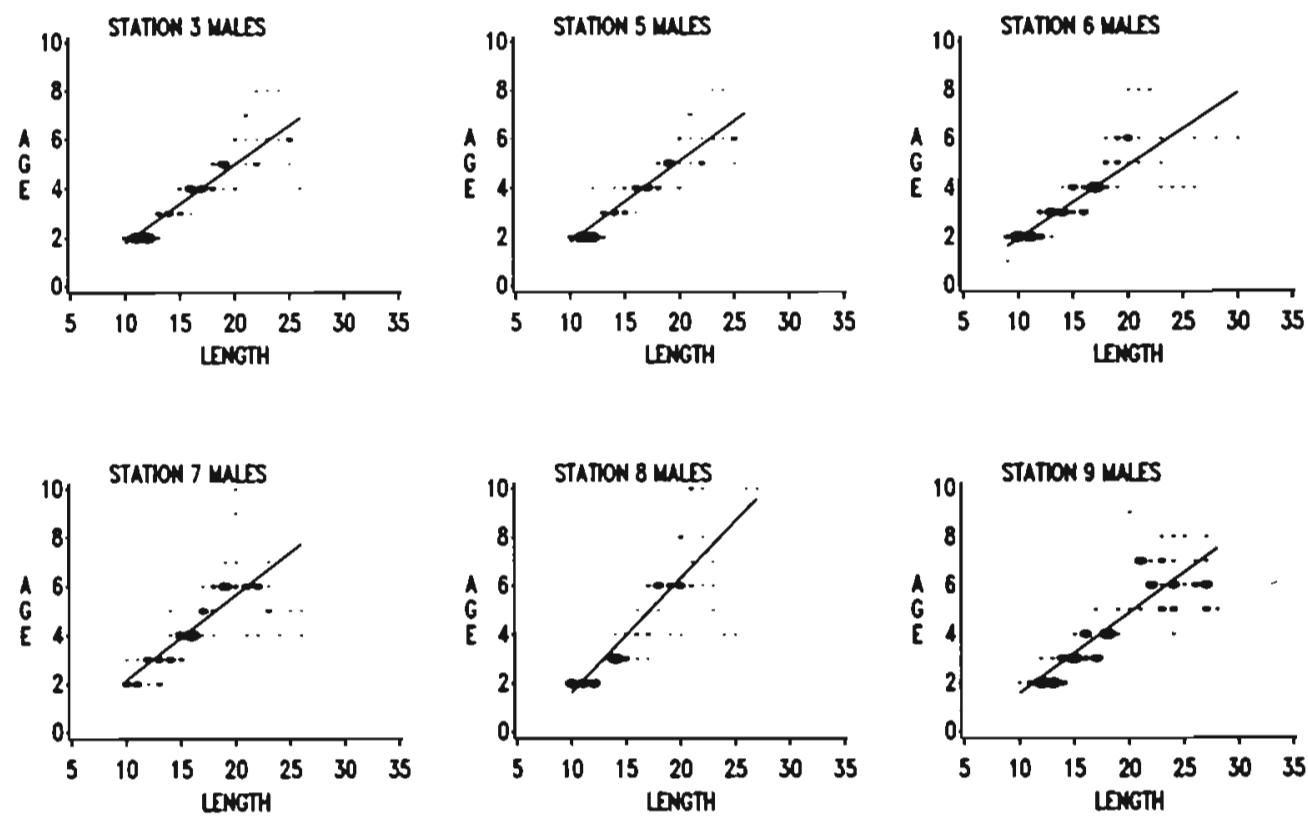

observer differences, or possibly to changes in the spatial patterns of this disease with time.

\section{Relationships with other potential risk factors}

Condition factor, somatic liver index and somatic gonad index all varied significantly among stations ( $p<0.01$; Fig. 5a to $c$ ). No significant associations were found between the occurrence of lymphocystis or epidermal hyperplasia/papilloma and these 3 factors, with

the exception of a strong negative correlation of lymphocystis with condition factor $(r=0.995 ; p<0.001)$.

Relative population densities of dab were particularly low at Stn 3 and high at Stn 5 (Fig. 5d). They showed no significant association with either disease.

Using mean values at each station, a strong positive correlation was found between the occurrence of epidermal hyperplasia/papilloma and concentrations of most contaminants in the livers of the fish, with the exception of $\mathrm{Cd}$, for which a significant negative correla- 
Table 9. Limanda limanda. Odds ratios for lymphocystis (Ly) and epidermal hyperplasia/papilloma (EP) in dab at each station during the 1 st and 2 nd surveys (odds ratios adjusted for sex and length)

\begin{tabular}{|ccccc|}
\hline Effect & Ly (1st) & Ly (2nd) & EP (1st) & EP (2nd) \\
\hline Stn 3 & 1.00 & 1.00 & 1.00 & 1.00 \\
Stn 5 & 1.26 & 1.37 & 0.86 & 1.37 \\
Stn 6 & 1.56 & 1.83 & 0.48 & 0.76 \\
Stn 7 & 1.43 & 1.78 & 0.35 & 0.65 \\
Stn 8 & 1.26 & 1.51 & 0.38 & 0.26 \\
Stn 9 & 2.17 & 2.01 & 0.23 & 0.40 \\
\hline
\end{tabular}

tion was found. This contrasted with the findings for lymphocystis, which showed the opposite trend (Table 11).

Using the individual haul data for contaminant concentrations and disease odds, no consistent pattern was found.

\section{DISCUSSION}

\section{Methodology}

The present findings demonstrate the value of histology for confirmatory diagnosis of gross lesions in fish. However, for the purposes of biological effects monitoring, such specificity may not be necessary for the external diseases studied here, because of their ease of macroscopic identification and their high prevalences. But when gross liver nodules are used as indicators of suspected neoplasia, it is essential to employ histological techniques to differentiate the many non-neoplastic lesions from true neoplasia. The strategy of detecting nodules $\geq 2 \mathrm{~mm}$ on the liver in order to collect information on neoplastic disease from large numbers of fish is appropriate, but should always be followed by histological confirmation. This study also indicates that it might be useful to record smaller lesions as indicators of early stages that may lead to neoplasia, but this should always be accompanied by histological confirmation.
Although an attempt was made here to control potential confounding factors, there were 2 major shortcomings. The first concerns the sample size and reliability of prevalence estimates. It is clear from this study that for diseases of low prevalence, linear logistic analysis cannot be used to test for differences between stations. This is particularly true for the ulceration and liver nodule data. Thus the minimal requirements recommended by ICES (ICES 1989; Table 1) may be too low.

The sampling design for liver nodules gave particular problems. Even though stratified sampling was used in an attempt to obtain sufficient large fish, there were very few male dab larger than $24 \mathrm{~cm}$. Thus even the sample sizes recommended by ICES could not be achieved. To increase the number of hauls per station is not a practical solution to this problem, since field work at sea is frequently constrained by bad weather, and ship time often restricted due to high costs.

The second shortcoming is related to the mobility of dab. Recent data show that migrations of dab, associated with spawning activities, occur over considerable distances (hundreds of $\mathrm{km}$ ) in the southeastern North Sea (Damm et al. 1991, Rijnsdorp et al. 1992). The workshop coincided with the peak spawning period of dab (February to April), with the German Bight transect (especially Stns 3, 5 \& 6) representing a major spawning ground of the species. The new data suggest that along the German Bight transect, in March, a net migration of dab from the offshore stations to the inner German Bight stations took place. Thus, dab caught at the inner stations during the workshop period probably represented mixtures of fish from offshore and coastal waters. This fact should be taken into account in interpreting epidemiological findings.

The workshop only involved samples taken during one month (March), but ideally, fish disease surveys should be repeated annually, preferably coinciding with a non-migratory period when disease prevalence is greatest. This is not feasible in the case of dab, which seems to have higher disease prevalences in spring than in autumn (at least in the southern part of the North Sea) (Wolthaus 1984, Vethaak 1985, Banning 1987), coinciding with the migratory period.

Table 10. Limanda limanda. Odds ratios (with $95 \%$ confidence limits) for lymphocystis (Ly) and epidermal hyperplasia/papilloma (EP) in male (M)/female (F) and old/young dab during the 1st and 2nd surveys (odds ratios adjusted for station/age and station $/$ sex)

\begin{tabular}{|c|c|c|c|c|}
\hline Effect & Ly (1st) & Ly (2nd) & $E P(1 s t)$ & $\mathrm{EP}(2 \mathrm{nd})$ \\
\hline$M / F$ & $\begin{array}{c}1.17 \\
(0.96-1.44)\end{array}$ & $\begin{array}{c}1.01 \\
\{0.79-1.29\}\end{array}$ & $\begin{array}{c}0.62 \\
(0.46-0.84)\end{array}$ & $\begin{array}{c}0.52 \\
(0.37-0.74)\end{array}$ \\
\hline Old/young & $\begin{array}{c}1.64 \\
(1.35-2.01)\end{array}$ & $\begin{array}{c}1.35 \\
(1.04-1.74)\end{array}$ & $\begin{array}{c}1.91 \\
(0.71-1.17)\end{array}$ & $\begin{array}{c}1.20 \\
(0.87-1.65)\end{array}$ \\
\hline
\end{tabular}




\section{Interpretation of spatial patterns}

The statistical analysis confirmed the wellknown finding that length and sex can be important factors in disease occurrence (Table 8), and thus must be taken into consideration when prevalence data are analysed. In principle, differences among stations in age-length relationships could account for some observed spatial variation in disease prevalence, but this turned out not to be the case in the present study (Tables $7 \& 10$ ).

Condition factor (CF) could help to explain variations in disease prevalence, since low values can indicate malnutrition, which could increase susceptibility to disease. At the same time, high values of the somatic liver index (SLI) could indicate consumption of fatty foods or possible toxic effects, while the somatic gonad index (SGI) is a measure of physiological stress associated with reproduction. In this study, although these 3 measures showed significant spatial variation (Fig. 5), there was only a relationship with disease prevalence in the case of lymphocystis, where high prevalences were associated with a low condition factor. There was no apparent relationship of disease prevalence with high population density, which again could in principle be related to stress (Fig. 5).

The prevalence of both epidermal hyperplasia/papilloma and lymphocystis showed an apparent relationship with the pollution gradient (Fig. 1). However, while the prevalence of the former disease was highest at the inner, most polluted stations, the converse was the case for lymphocystis. This relationship was confirmed by significant correlations found with contaminant concentrations (Table 11). In the case of liver abnormal-
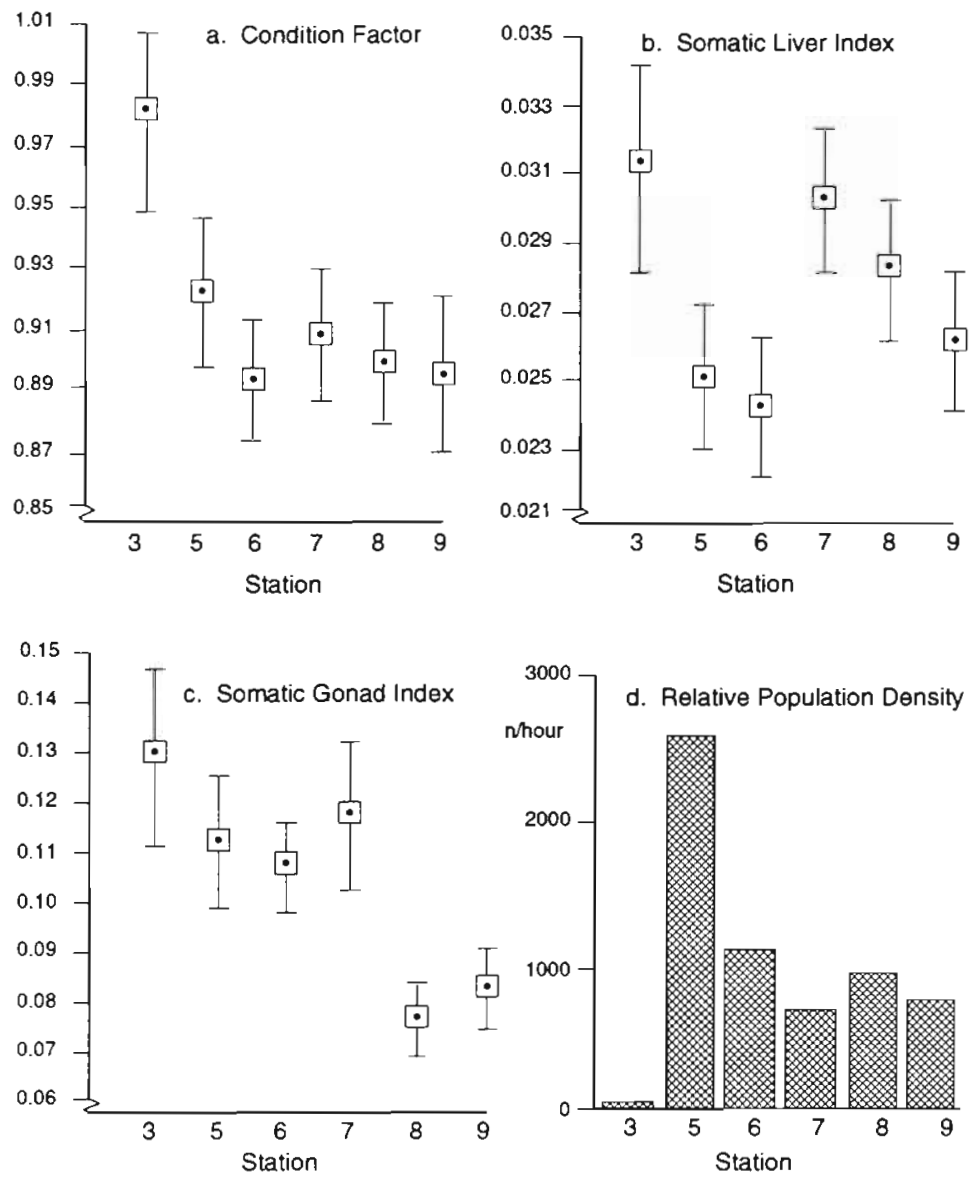

Fig. 5. Limanda limanda. Mean values ( $\pm 95 \%$ confidence limits) of (a) condition factor, (b) somatic liver index, and (c) somatic gonad index, in dab at each station. Also (d) relative population density at each station, expressed as the number of dab $\geq 15 \mathrm{~cm}$ length caught per hour

ities, the prevalences were generally too low to allow a realistic evaluation of pollution effects.

Gross liver nodules were observed at all stations on the German Bight transect. Upon histological exam-

Table 11. Limanda limanda. Log disease odds for lymphocystis (Ly) and epidermal hyperplasia/papilloma (EP), together with mean concentrations (ng g ${ }^{-1}$ lipid) of 5 PCB congeners, $\mathrm{HCB}$, and lindane, and also $\mathrm{Cd}_{\text {(ng }} \mathrm{g}^{-1}$ wet weight) in the livers of dab at each station. Also correlation coefficients between log disease odds and contaminant concentrations. All data refer to female dab (length $20-24 \mathrm{~cm}$ ). $\mathrm{p} p<0.05$

\begin{tabular}{|c|c|c|c|c|c|c|c|c|c|c|}
\hline & Ly & $\mathrm{EP}$ & CB-28 & CB- 101 & CB-138 & CB- 153 & CB- 180 & $\mathrm{HCB}$ & Lindane & $\mathrm{Cd}$ \\
\hline $\operatorname{Stn} 3$ & -3.07 & -1.79 & 13.3 & 127 & 399 & 496 & 102 & 35 & 52 & 52 \\
\hline Stn 5 & -2.35 & -1.76 & 9.3 & 92 & 275 & 327 & 61 & 43 & 35 & 95 \\
\hline Stn 6 & -2.07 & -2.40 & 8.5 & 79 & 182 & 217 & 41 & 33 & 34 & 114 \\
\hline Stn 7 & -2.16 & -2.81 & 5.4 & 40 & 108 & 135 & 35 & 29 & 31 & 123 \\
\hline Stn 8 & -2.09 & -2.71 & 6.5 & 59 & 128 & 159 & 38 & 32 & 25 & 167 \\
\hline Stn 9 & -1.97 & -3.30 & 6.4 & 50 & 119 & 157 & 30 & 35 & 9 & 162 \\
\hline \multirow{2}{*}{\multicolumn{3}{|c|}{$\begin{array}{l}\text { Ly correlation coef. (r) } \\
\text { EP correlation coef. ( } r \text { ) }\end{array}$}} & $-0.85^{\circ}$ & -0.78 & $-0.86^{\circ}$ & $-0.88^{\circ}$ & $-0.96^{\circ}$ & -0.23 & -0.68 & $+0.95^{\circ}$ \\
\hline & & & $+0.84^{\circ}$ & $+0.87^{\circ}$ & $+0.91^{\circ}$ & $+0.89^{\circ}$ & $+0.89^{\circ}$ & +0.57 & $+0.84^{\circ}$ & $-0.83^{\circ}$ \\
\hline
\end{tabular}


ination, only $30 \%$ of them were diagnosed as hepatocellular adenoma (neoplasia). These occurred at most stations, including the offshore Stns 8 \& 9. The histological examination of gross liver nodules also revealed a wide range of pathomorphological changes which are not considered neoplastic. However, contaminants may cause changes in the morphological structure or contents of cell types in various tissues and organs. These features may not necessarily be, or lead to, pathological changes (including neoplasia), but can reflect the health of fish by showing depletions or replenishment of storage products, e.g. lipids and glycogen, or can specifically demonstrate the sites of deposited metals in the tissues.

Although hepatic lesions recorded in the dab samples were categorised by their histological characteristics, there remained the problem of the significance of the non-infectious lesions, in particular, the foci of cellular alteration. Myers et al. (1987) discussed the subject at length and proposed that for the English sole Parophrys vetulus, a North American pleuronectid species, the development of hepatocellular neoplasia was closely similar to that in rats and certain fish species experimentally exposed to carcinogens. They pointed out that, because controlled experiments had not been conducted with English sole, this only constituted strong circumstantial evidence that the fish had been exposed in the long-term to a large number of hepatocarcinogens and hepatotoxins. For practical reasons we propose to follow the same classification of liver lesions for dab, although in this material the spectrum of lesions is rather limited. Whether all the foci observed in this study are pre-neoplastic changes is arguable; for example, the storage material content in hepatocytes in flounder Platichthys flesus livers has been shown to deplete and replenish after starvation and re-feeding (Segner \& Möller 1984). Timoshova (1981) demonstrated that remarkable changes in amounts of storage material occurred in livers of plaice Pleuronectes platessa in response to seasonal changes.

The validity of the observed spatial patterns of diseases depends critically on the mobility of dab. As discussed above, this implies that caution should be taken in the interpretation of prevalence values along the German Bight transect. In assessing spatial differences in disease prevalences, the relationship between the extent of migration and the time taken for the disease to develop must be considered. The 4 externally visible diseases investigated in this study have a known (or suspected) infectious aetiology. However, this is not the case for liver neoplasia, which can be characterised as a probable chronic non-infectious disease, with development likely taking place over several years. Therefore, while information on fish mobility may be relatively less important for acute infectious skin dis- eases, it is essential for the correct interpretations of data on liver neoplasia. Spatial (or temporal) patterns of this disease can only be clarified with adequate knowledge of fish migratory patterns, including the nursery grounds of juvenile fish, and areas and time of residence during the adult phase.

When these epidemiological findings are compared to the results of many other surveys of diseases in dab reported in the literature, there appears to be a remarkable coherence. With the possible exception of epidermal hyperplasia/papilloma, there is no convincing evidence for the existence of a causal link with pollution (Vethaak \& ap Rheinallt 1992). Both Vethaak \& van der Meer (1991) and Dethlefsen et al. (1987) found higher prevalences of epidermal hyperplasia/papilloma in former titanium dioxide dumping areas in Dutch coastal waters and the German Bight respectively. However, while Dethlefsen et al. (1987) found clear correlations between disease and chemical factors, Vethaak \& van der Meer (1991) did not. The latter authors concluded that interpretation of a causal link was complicated by various factors including possible local migration of dab. Mellergaard \& Nielsen (1987) studied the temporal relationship of epidermal hyperplasia/papilloma in dab in Danish coastal waters with oxygen depletion in this area, and found indications of causality. On the other hand, studies from other areas, such as the Irish Sea and Scottish waters, failed to show a positive correlation between epidermal hyperplasia/papilloma and pollution (Bucke \& Nicholson 1987. McVicar et al. 1988). Similarly, findings reported over wider areas of the North Sea (Dethlefsen et al. 1987, Bucke \& Stokes 1988) did not suggest any clear interpretation. It is possible that the results of many of the above-mentioned studies were biased by substantial mobility of the dab populations sampled.

The data on liver neoplasia from the present study are inconclusive. However, there is an increasing amount of literature, especially from North American studies, supporting the case that liver neoplasia in pleuronectids is caused by Polycyclic Aromatic Hydrocarbons (PAH) and perhaps other chemicals (see reviews by Mix 1986, Malins et al. 1988). The phenomenon of liver neoplasia and related lesions has been studied in the North Sea by various investigators (Vethaak \& ap Rheinallt 1992, Bucke \& Feist 1993). In general the results of these studies show that liver neoplasia and putative preneoplastic lesions are not restricted to dab from the more polluted coastal margins of the North Sea, but that relatively high levels also occur in the central North Sea, including the Dogger Bank (Stn 9 of this study) (Kranz \& Dethlefsen 1990). The distribution pattern of liver tumours along the German Bight transect could be the result of migrating dab spending their juvenile stages in more polluted coastal 
waters (nurseries), then moving offshore when older, but at the moment this remains speculative. However, the true significance of the disease can only be evaluated with knowledge of the natural background frequencies of disease in the absence of chemical pollution, which have still not been established.

\section{CONCLUSIONS AND RECOMMENDATIONS}

The findings of the study, in conjunction with the available evidence from other studies, indicate that the most promising external disease for biological effects monitoring appears to be epidermal hyperplasia/papilloma. Putative pre-neoplastic and neoplastic liver lesions have been recommended as a suitable internal disease for use in biological effects monitoring, although they were only found at low prevalences in this study. However, before these diseases can be used as reliable indicators, there are several areas that need further research, including migratory patterns of dab, the natural background frequencies of disease, and causal relationships to be investigated by laboratory experiments.

The sampling strategy and methodology applied in the study and adopted by ICES is reliable and suitable for monitoring common diseases. However, the minimal sample size requirements recommended by ICES (1989) are too low to allow the detection of spatial or temporal trends in diseases of low prevalence, especially liver neoplasia. In studies of liver nodules, it is strongly recommended that histological techniques should be included, to confirm the identity of grossly visible lesions, as well as to conduct routine investigations of apparently healthy livers.

Acknowledgements. The authors thank the crews of the 2 German research vessels RV 'Solea' and RV 'Walther Herwig' (both from the Bundesforschungsanstalt für Fischerei) and to B. Lienstädt, U. Marggraf, U. Völker, J. Dethlefsen and S. Wilhelms for their help with the field work and data processing. We are grateful to $R$. Jungcurt for producing the illustrations.

\section{LITERATURE CITED}

Baker, R. J., Nelder, J.A. (1978). The GLIM system, Release 3. Generalized Linear Interactive Modelling, Numerical Algorithms Group, Oxford

Banning, P., van (1987). Long-term recording of some fish diseases using general fishery research surveys in the southeast part of the North Sea. Dis. aquat. Org. 3: 1-11

Bloch, B., Mellergaard, S., Nielsen, E. (1986). Adenovirus-like particles associated with epithelial hyperplasias in dab (Limanda limanda). J. Fish Dis. 9: 281-285

Bucke, D., Feist, S. W. (1993). Histopathological changes in the livers of dab Limanda lim anda. J. Fish Dis. (in press)

Bucke, D., Nicholson, M. D. (1987). Fish disease status in the Irish Sea. CM/ICES E19: 1-12
Bucke, D., Stokes, K. (1988). Fish disease monitoring on the 1987 North Sea groundfish survey. CM/ICES E7: 1-10

Bucke, D., Watermann, B. (1988). Effects of pollutants on fish. In: Salomons, W., Bayne, B. L., Duursma, E. K., Förstner, V. (eds.) Pollution of the North Sea: an assessment. SpringerVerlag, Berlin, p. 612-623

Bucke, D., Vethaak, A. D., Lang, T (1993). Training guide for the identification of common diseases and parasites of fish in the North Atlantic. ICES Coop. Res. Rep. (in press)

Cofino, W. P., Smedes, F., de Jong, S. A., Abarnou, A., Boon. J. P., Oostingh, I., Davies, I. M., Klungsøyr, J., Wilhelmsen, S., Law, R. J., Whinnett, J. A., Schmidt, D., Wilson, S. (1992). The chemistry programme. Mar. Ecol. Prog. Ser. 91: $47-56$

Cox, D. R. (1970). The analysis of binary data. Chapman \& Hall, London

Damm, U., Lang, T., Rijnsdorp, A. D. (1991). Movements of dab (Limanda limanda) in the German Bight and Southern Bight, results of German and Dutch tagging experiments in 1988, 1989. CM/ICES E22: 1-14

Dawe, C. J. (1981). Polyoma tumours in mice and X-cell tumours in fish viewed through telescope and microscope. In: Dawe, C. J. et al. (eds.) Phyletic approaches to cancer. Jpn Sci. Soc., Tokyo, p. 19-49

Dethlefsen, V., Watermann, B., Hoppenheit, M. (1987). Diseases of North Sea dab (Limanda limanda L.) in relation to biological and chemical parameters. Arch. Fisch Wiss. $37 \cdot 107-237$

ICES (1989). Methodology of fish disease surveys. Report of an ICES Sea-Going Workshop held on U/F 'Argos' 16-23 April 1988. ICES Coop. Res. Rep. No. 166

Kranz, H. M., Dethlefsen, V (1990). Liver anomalies in dab Limanda limanda from the southern North Sea with special consideration given to neoplastic lesions. Dis. aquat. Org. 9: 171-185

Malins, D. C., McCain, B. B., Landahl, J. T., Myers, M. S., Krahn, M. M., Brown, D. W., Chan, S. L., Roubal, W. T. (1988). Neoplastic and other diseases in fish in relation to toxic chemicals; an overview. Aquat. Toxicol. 11: 43-67

McCullagh, P., Nelder, J. A. (1989). Generalised linear models, 2nd edn. Chapman and Hall, London

McVicar, A. H., Bruno, D. W., Fraser, C. O. (1988). Fish diseases in the North Sea in relation to sewage sludge dumping. Mar. Pollut. Bull. 19: 169-173

Mellergaard, S., Nielsen, E. (1987). The influence of oxygen deficiency on the dab population in the eastern North Sea and the Southern Kattegat. CM/ICES E6: 1-24

Mix, M. C. (1986). Cancerous diseases in aquatic animals and their association with environmental pollutants: a critical literature review. Mar. environ. Res. 20: 1-141

Möller, H., Anders, K. (1986). Diseases and parasites of marine fishes. Möller, Kiel

Myers, M. S., Rhodes, L. D., McCain, B. B. (1987). Pathologic anatomy and patterns of occurrence of hepatic lesions, and other idiopathic hepatic conditions in English sole (Parophrys vetulus) from Puget Sound, Washington. J. natn. Cancer lnst. 78: 333-361

Rijnsdorp, A. D., Vethaak, A. D., van Leeuwen, P. I. (1992). Population biology of dab Limanda limanda in the southeastern North Sea. Mar. Ecol. Prog. Ser. 91: 19-35

Sindermann, C. J., Bang, F. B., Christensen, N. O., Dethlefsen, V., Harshbarger, J. C., Mitchel, J. R., Mulcahy, M. F. (1980). The role and value of pathobiology in pollution effects monitoring programs. Rapp. P.-v, Réun. Cons. int. Explor. Mer 179: 135-151

Segner, H., Möller, H. (1984). Electron microscopical investigations on starvation-induced liver pathology in 
flounder, Platichthus flesus. Mar. Ecol. Prog. Ser. 19: $193-196$

Stebbing, A. R. D., Dethlefsen, V. (1992). Introduction to the Bremerhaven Workshop on Biological Effects of Contamination. Mar. Ecol. Prog. Ser. 91: 1-8

Timoshova, L. V. (1981). Seasonal changes in the structure of the liver of the plaice, Pleuronectes platessa. J. Ichthyol. 21: $145-154$

Vethaak, A. D. (1985). Prevalence of fish diseases with reference to pollution of Dutch coastal waters. Netherlands Institute for Fishery Investigation (RIVO), IJmuiden,
Report CA 8501: 1-70

Vethaak, A. D., ap Rheinallt, T. (1992). Fish disease as a monitor of marine pollution: the case of the North Sea. Rev. Fish Biol. Fish. 2: 1-32

Vethaak, A. D., van der Meer, J. (1991). Fish disease monitoring in the Dutch part of the North Sea in 1986-88 in relation to the dumping of waste from titanium dioxide production. Chem. Ecol 5: 149-170

Wolthaus, B. G. (1984). Seasonal changes in frequency of diseases in dab, Limanda limanda, from the southern North Sea. Helgoländer Meeresunters. 37: 375-387 